Portland State University

PDXScholar

2015

\title{
Algeria in Perspective: Changing the Understanding of the Modern Algerian State
}

Austin Averett

Portland State University

Follow this and additional works at: https://pdxscholar.library.pdx.edu/honorstheses Let us know how access to this document benefits you.

\section{Recommended Citation}

Averett, Austin, "Algeria in Perspective: Changing the Understanding of the Modern Algerian State" (2015). University Honors Theses. Paper 198.

https://doi.org/10.15760/honors.197

This Thesis is brought to you for free and open access. It has been accepted for inclusion in University Honors Theses by an authorized administrator of PDXScholar. For more information, please contact pdxscholar@pdx.edu. 
Algeria in Perspective:

Changing the understanding of the modern Algerian state.

by

Austin Averett

An undergraduate honors thesis submitted in partial fulfillment of the requirements for the degree of

Bachelor of Arts

in

University Honors

and

Applied Linguistics

Thesis Adviser

Lindsay Benstead

Portland State University 


\begin{abstract}
Much of the existing literature on the modern state of Algeria reinforces rivalry-based understandings of the politico-linguistic infrastructure that overemphasize the presence of a dichotomy (French v. Arabic) in the linguistic make up of the state. Many studies rely on this construction of an Algerian language dichotomy to predict the future of the state, while; in fact, more attention should be paid to the multilingual, multicultural, and multinational reality of the larger demographic. Algeria's history of language rationalization has laid the foundation for unique institutional reflections of state power dynamics within a multilingual environment. Discussions of Algeria’s historical background, identity construction, revolutionary movements, nationalism, and the future of Algerian governance would benefit from a more comprehensive and interdisciplinary exploration of the language attitudes that exist across demographics. This paper explores works by sociolinguists such as Hafid Gafaïti, Wallace Lambert, and Mohamed Benrabah and political scientists such as Lindsay Benstead, Amaney Jamal, and Megan Reif to develop how sociolinguistic survey methodologies such at the Matched Guise technique might be utilized to form a better understanding of Algeria's political prospects.
\end{abstract}

Keywords: Algeria, language hegemony, post-colonialism, nationalism, democratization, Arabic, French, Tamazight, multilingualism, multiculturalism, mononationalism. 


\section{There are few countries as little studied and as much misunderstood as modern Algeria, at least in the English-speaking world.}

- Martin Stone, The Agony of Algeria (1997, p.1)

\section{Introduction}

According to Martin Stone, Algeria has been understudied and overlooked as a state, perhaps especially of late as the world's attention has been turned towards other North African states experiencing significant political unrest (i.e. Tunisia, Libya, and Egypt). Interestingly, his qualifying addition “.... at least in the English-speaking world” makes a perhaps unintentional nod to the role that language has played in the Algerian case. Stone means to highlight the extent to which French and Algerian scholars have explored the Algerian situation, which literature in English has neglected. However his quote also subtly touches on the idea of how language is an integral component of any Algerian study.

North Africa is the site of the 2011 Arab Uprisings, otherwise known as the Arab Spring, and the series of events that have occurred in its wake will certainly continue to have effects on the region. Algeria in particular is a unique case, and the question of how the Algerian state dealt with the impact of the regional upheaval has been asked by political scientists, sociologists, and experts within a variety of other disciplines. Though it is disingenuous to claim that Algeria did not participate in the Arab Uprisings, the country did not experience the level of political unrest that its neighbors of Tunisia, Libya, and Egypt did. There were minor protests and calls for democratic reform that echoed those in the nearby countries, though the Algerian regime only responded with limited liberalization of existing policies and limited economic cushion. In the 
wake of these events, I contend that it is important to revisit the discussion of Algeria's linguistic history and the implications of multilingual communities existing within a mononational ${ }^{1}$ state.

This thesis will first explore the historical background of Algeria both from a political and a linguistic angle. As is to be expected from such a linguistically diverse environment, at many points throughout the state's history, these two facets are indivisibly enmeshed. Next, there will be an exploration of linguistic theory. This will include a minor focus on sociolinguistic survey methodology called the Matched Guise Technique and how it and similar language attitude studies can both help garner knowledge and potentially hinder social and political movements. Thirdly, this thesis will propose that this type of interdisciplinary work is the necessary component to developing a more comprehensive and better-understood picture of the modern Algerian context.

\section{Algeria's Background}

Algeria is a fascinating politico-linguistic case study, in part due to its unique pre-colonial, colonial, and post-independence history compared to the parallel history of the neighboring states. The state withstood a longer, harsher colonial period than Morocco and Tunisia, as well as fighting a decidedly more violent war for independence and a significant internal civil war in the 1990s. Since winning independence, the longstanding nationalist regime of Algeria has steered the state away from much of the cultural acclimation to the legacy and infrastructure left by France. One of the clearest signals of this intent is seen in how discussion of the language issue is dealt with by state policies. As the young state has matured, language has been both a dividing

\footnotetext{
${ }^{1}$ As far as the centralized government of Algeria is concerned, the state is a mononational one.
} 
and central factor within political and cultural movements. On the other hand, Algeria readily adopted the French tradition of Jacobinism that guides today's state with a strong centralized and socialist government (Benrabah, 2014). The form of government that harkens back to the revolutionary movements of France is now the same form of government that resisted a thread of upheaval at a time when revolution was occurring all across North Africa.

It is important to acknowledge the pre-colonial context of Algeria as a subtle foundation to the context of the modern state. The indigenous communities that populated the region during the Ottoman Empire still have strong voices in the modern state, some demographics more so than others. While the Ottoman Empire didn't fully collapse until the early 1900s, the region it covered began shrinking decades earlier. North Africa, originally a fairly self-governed sphere within the empire, saw a wave of European colonization much earlier than the Gulf and Levant states. Algeria was the earliest of the colonized regions in North Africa (Lust, 2014).

Though much of the scholarly conversation emphasizes the influence of the colonial era on the modern day language trends, it is important to remember that there was an existing language environment far before the era of French colonialism. Hafid Gafaiti, an Algerian scholar who left the country in the aftermath of the civil war, introduces part of his argument with a reminder that much of Algeria has a history of the oral transmission of culture. Indigenous communities include five distinct Berber ${ }^{2}$ cultures, most notably the Kabyle. Prior to French colonization, the prominent languages of Algeria included these varieties of Berber languages and the colloquial variation of Arabic (Gafaiti, 2002). These indigenous languages and the communities that speak

\footnotetext{
${ }^{2}$ The term Berber comes from the word Barbary, which, according to the Oxford English Dictionary, was ascribed to the indigenous people of North Africa by Arab geographers and refers to the region as a "land of barbarians" (Oxford English Dictionary).
} 
them were both marginalized and, to a limited extent, supported during the colonial era. Many Algerian intellectuals have come from within the Berber communities and their training often occurred overseas in academic institutions in France.

\section{Colonial Era}

Compared to its neighbors, Morocco and Tunisia, the colonial period in Algeria was significantly longer and much more destructive. Algeria became a protectorate of France in $1830^{3}$. As the colonial force, France's modus operandi was to deconstruct the entire existing infrastructure of the society, and replace it with the French approach to governance (Taleb Ibrahimi, 1997). Any existing economic, political, judicial, academic, etc. institutions were restructured to indoctrinate the North African society with the dogma of French society. Taleb Ibrahim cites the Minister of Education of 1897, A. Rambaud, who explains the series of conquests by the French against Algerian society:

The first conquest of Algeria was accomplished by the military in 1871 with the disarming of the Kabyle. The second conquest consisted of making the indigenous accept our administration and our justice. The third conquest will be done by the school: it will ensure the dominance of our language over the various local dialects, instilling into the Muslims the idea that we are all of France and for its role in the world... ${ }^{4}$ (p. 37)

\footnotetext{
${ }^{3}$ Tunisia and Morocco became French protectorates in 1881 and 1912, respectively. (CIA, 2013)

4 "La premiere conquete de l'Algerie a été accomplice par les armes et s'est terminée en 1871 par le désarmement de la Kabylie. La seconde conquête a consisté à faire accepter par les indigenes notre administration et notre justice. La troisieme conquête se fera par l'Ecole: elle devra assurer la predominance de notre langue sur les divers idioms locaux, inculquer aus musulmans l'idée que nous avons nous-mêmes de la France et de son role dans le monde..." A. Rambaud (Taleb Ibrahimi, 1997, p.37)
} 
Rambaud's quote illustrates the deliberate course that France took to assimilate Colonial Algeria into French culture. However, his word choice as he labels the French language "notre langue" against the indigenous "idiomes locaux" gives away a classic example of the orientalist, racist attitude towards colonized cultures. In this instance, it is clear that this same distinction is being made between the civilized French language and Algerian "dialects", which were seen as unsophisticated- an attitude that has been internalized and is still ascribed to colloquial variations today ${ }^{5}$. Though much of the pre-colonial history was stripped away by the ferocity of French acculturation during the colonial period, the indigenous culture and heritage is still present in the variety of Berber cultures that exist in Algeria today. Algeria's long period of colonial oppression under the French included a promotion of the French language as the official language of Algeria, and the labeling of Arabic as a "foreign language" in 1938.

The expanse of literature on orientalism ${ }^{6}$ as it relates to North Africa and the region's colonial period is useful to help understand the colonial tactic to foster elites from minority communities (i.e. the indigenous Berber cultures). During the colonial era, France made deliberate moves to foster elites from within each community in order to appease those who, if unsatisfied, had enough social leverage to push back against colonial rule. Alongside this strategy, the colonial force had a history of catering to an extent to minorities, a tactic that has

\footnotetext{
5 "The debasement of dialectical Arabic has reinforced the diglossic condition of Algerians", with implications for both gender and generational spectrums (Berger, 2002). Diglossic being a linguistic term for speakers using two (or more) language variations in their daily life. Today, youth educated in Arabized classrooms grow up to not speak the same variety of Arabic their fathers, and more often, their mothers speak. This has lead to attitudinal shifts relating to language and only reinforces the generational differences that reflect a shift in identity construction and the individuals' relationships to Algeria's colonial and indigenous past. ${ }^{6}$ Said (1977) explores a variety of definitions of orientalism. I aim to remind readers that, in a general sense, the idea of orientalism serves to provide a distinction between the West (European and American powers) and the Orient (any culture which might be "other"). Western powers, like France, colonizing North Africa are inextricably involved in Orientalized thinking because of their blatant labeling of the indigenous groups as "other", uncivilized, barbaric, etc.
} 
long been used to stratify communities so as to maintain a vice grip on power. For example, via the Decret Cremieux, France granted French citizenship automatically to 37,000 Jews, which was not made available to Algerian Muslims, etc. (Dourari, 2014). Similarly, the French government often aligned itself with the Kabyle community ${ }^{7}$. Excepting a few elite from the Arab communities, to be Arab in colonial Algeria was to be foreign and barbarian, while the Berber community ${ }^{8}$, in particular the Kabyle, saw less marginalization by the French. In many cases, Kabyle communities were sponsored, by the French, as a gambit in France's “divide and rule" strategy. Kabyles were often educated within the private academic institutions and given special treatment over the Arab majority. (Dourari, 2014)

This community is not only significant due to their history as a less marginalized class of the colonial period but also because of the ideological stance they aligned themselves with during the independence struggle and their civil and political presence since. The modern rivalry between Kabyle and state groups originated in colonial times and became more pronounced during and in the aftermath of the independence struggle (Benrabah, 2014). Though both groups saw a future for an independent Algerian state, there was a conflict of interest where the question of identity lay. The Kabyle vision of an "Algerian Algeria" is a secularist, inclusive one. (Benrabah, 2014) In the more recent years (early 2000s) the Kabyle movement to promote linguistic pluralism and cultural inclusion has become a broader movement that incorporates the goals and aspirations of the younger generation of Algeria. Since the Berber Spring, the Kabyle

\footnotetext{
${ }^{7}$ The Kabyle are the largest of the minority Berber demographics in Algeria, followed by the Chouia, the Mzab, and the Tuareg... (CIA, 2013)

${ }^{8}$ Historically, there is a debate surrounding whether the Berber cultures are linked to a European bloodline. As such, there is a rhetoric surrounding the Berber cultures' ability to be easily civilized in a way that Arabs are not thought of as civilizable. This point of contrast between the Berberophone and Arabophone Algerians is one of those attitudinal relics from the colonial era that has been reshaped into the continued rivalry between the modern-day communities.
} 
movement has begun calling more broadly for democratic reform and a liberalization of the NLF's policies, including for liberalized, pluralistic educational policies that the original reformist Kabyle leadership of the older generation sought. Despite the Kabyle legacy that rejects the Arab-Islamic identity prescribed by the NLF government, it is undisputed that Islam \& Classical Arabic functioned as revolutionary tools against French colonialism. (Dourari, 2014)

\section{Algerian Independence}

As Algerians were fighting against the colonial power, there were two major factions of anticolonial resistance. The reformist movement, which is linked to a pluralist and largely Kabyle community, and the nationalist movement, which is linked to the current regime. The National Liberation Front (FLN in the French acronym), still the dominant conservative party of the modern state, are steadfastly aligned with a mononational Arab-Islamic identity. The reformist movement, which worked alongside the nationalists in the fight for independence, originated from within the Berber community. They too called for an independent Algeria, yet envisioned a future state that would be a pluralistic, cohesive vision of what would remain of the colonial era. Immediately upon entering the era of Algerian statehood, these two political forces that had worked together to win an independent state split. The nationalist movement consolidated into the centralized government that is still the current regime, while the reformists were excluded from the newly formed government.

The new FLN regime, for a short time under the elected president Ahmed Ben Bella, and later under President Boumédiène, nationalized the economy of Algeria and steered clear of liberalizing modernization policies. As a socialist regime, the premise of the new state was to support the poor classes within Algeria and boost the economy, which up until the discovery of 
oil in 1956 during the war for independence, had relied upon agricultural and mineral industries. The nationalization of the state's economy, now largely based on oil revenue, would support the regime as well as provide subsidies and public goods to the populace (Lust, 2014). However, in the subsequent years, this intention fell to the wayside. Now, the implications of the economic structuring by the FLN have lead to severe underemployment and economic stability within lower classes and youth demographics.

As the nationalist FLN regime failed to provide necessary goods and services, leaving Algerians to worry about employment, housing, medical facilities, and education, President Boumédiène died in 1978 (Lust, 2014). The disappearance of his personable and strong leadership role left the state in the hands of Chadli Benjedid, who did not have the same comprehensive grip on Algerian leadership. A populace worried about their livelihoods and living conditions engaged in protests across the country throughout the 80 s, culminating in a major national outburst of 1988. It was during this same period of time that the regime's educational policy known as Arabization began to falter. It is salient to make note of its paralleled time frame alongside the protests of the 1980s, and it is relevant to further explore the implications of the regime's stringent language policies.

Upon independence, Arabic was quickly adopted by the new nationalist state as the "official language" without any parallel acknowledgment of the native Berber languages. In fact, shortly thereafter, Berber culture and the Berber languages were banned under the centralized FLN regime that has remained in power since 1956 . Bouteflika, the current president has outwardly spoken against the Berber cultures and languages. In 1976, a presidential ordinance announced the "total Arabization" (Benrabah, 2014) of the Algerian infrastructure. The Arabization policies enforced the marginalization of the Berber languages and have certainly reinforced attitudes 
towards the French language. In modern Algeria, Tamazight wasn't acknowledged as a national language until 2002. Only recently has there been institutional room made for the teaching of Berber languages. Though throughout the 1970s, the Arabization movement had been gaining strength and momentum, the Berber Spring of the 80 s brought that trajectory of "totalized Arabization" to a trickle. In the 1980s, the Berber issue came to the forefront of the political atmosphere resulting from a series of protests and riots, largely by Kabyle leadership and Kabyle youth who were rebelling against their Arabized academic environment (Benrabah, 2014).

\section{Antecedents of Algerian Uprisings}

There are connective fibers that link the series of cultural and revolutionary movements that have occurred in Algeria. The Algerian Berber Spring of the 1980s, the protests of October 1988, the "civil war" of the early 90s, the Black Spring of 2001, and the Arab Uprisings of 2011 all share common threads that are emerging from Algeria's colonial and post-independence history. Throughout these significant moments in Algeria's history, there are through lines grounded in the intersection of culture, often oriented around the issue of language, and the challenging of the political status quo. Demographically, Algeria is racially and religiously homogeneous (CIA, 2013), an idea which has only been bolstered by the state-promoted concept of Algerian identity. Policies such as educational Arabization were tools to reinforce this identity. Despite the state's homogeneity, plurality is a foundational characteristic of Algeria. Though the racial and religious distinctions are few, Algeria is uniquely diverse in regards to its tribal, linguistic, and geographic communities (Dourari, 2014). Many of these moments in Algeria's history centered around or grew out of movements calling for authentic cultural representation.

\section{The Berber Spring}


The Berber Spring was a period beginning in 1980 and continuing through the 80 s, as the face of the regime was changing. While the Berber Spring is uniquely connected to cultural and linguistic rights, specifically those of the Berber (largely Kabyle) community, as the 80s wore on other segments of the country also participated in protests. Weakened leadership and growing economic pressures on youth and the lower classes lead to a series of protests in the late $80 \mathrm{~s}$. In 1988, the protests grew to a climax and there were protests in Algiers and other urban centers against economic circumstances, oil wealth distribution, and for democratic reform (Ibrahim, 1988).

\section{The Algerian civil war \& Near Democracy}

Following the Berber Spring and the nationwide protests against the nationalist regime and its policies, the Algerian government made major adjustments to the party laws and electoral process (Lust, 2014). Party restrictions were lifted and a variety of new political parties were formed. Elections were held in the early 1990s and, in a surprising turn of events, in 1992 an Islamist party (Islamic Salvation Front; FIS) won municipal elections. The FLN was scrambling to regain power and the military ${ }^{9}$, a pillar of the nationalist regime, cancelled the next round of

${ }^{9}$ The colloquial name for the military in Algeria (La Pouvoir) means power. Algeria's deep state/military structure is much like Egypt's, though Algeria did not see the same revolution as Egypt due to the alignments between the regime and the military. The deep state in Egypt is ostensibly in charge of the government, whereas in Algeria the military and regime are more intertwined. Recently though, Algerian police and security forces have been involved in some of the protests for higher wages during the Arab Spring, and despite their wages being fairly high, there is some contention between the state and its security forces because of this factor. This, to me, begs a question about the regime's monopoly over the exercise of military force. 
presidential elections. The FLN was reinstalled as the leadership of the state, under the guise of a multiparty system. The resulting upheaval buried the country in a decade of devastating civil war in which thousands were killed, arrested, and tortured.

In her discussion of Algerian civil society, Andrea Liverani assesses the diversity of the associational life ${ }^{10}$ within the state. Distinct tribal affiliations and community interests led to hundreds of new associative movements in the 1990s. Liverani demostrates that much of the mainstream dialogue surrounding this multitude of civil society movements treats the phenomenon as something indicative of the state's growing social capital and trust; however, Liverani contends that this growth of associative movements is more likely born out of a highly stratified community that lacks social trust. She writes that "rather than a locus of reciprocity, solidarity, and cooperation, associations appear as the byproduct of increasingly conflict-ridden social relations..." and seem to be serving as a coping mechanism for the political change that occurred in the wake of the uproar of the 90s (Liverani, 2008).

In Barriers to Democracy, Jamal (2007) reminds readers of the longstanding debate over the significance of the strength of associational life. Though a strong civil society may in some ways promote democratic ideals and practices, there are certainly devoutly authoritarian regimes with populaces that participate in a vibrant associational network. It could be argued that Algeria is one such state. For some scholars, it remains to be seen whether the strength of associational life can be considered an indicator of eventual democratization (Jamal, 2007).

\section{The Black Spring}

${ }^{10}$ Associational life is often an interchangeable term with civil society. 
Towards the end of Algeria's civil war in 2001, more protests erupted from within student demographics. These movements were from within a Kabyle demographic calling, once again, for cultural inclusion by the regime of the Berber communities; such as recognition of their language(s) and an educational system inclusive of those languages. It was at this stage that the regime made some concessions, labeling Tamazight a "national language" and promoting minor efforts to include it into the state's educational framework (Raymond \& Ali, 2014). Changes such as these often seem little, and in some cases within authoritarian regimes, are no more than policies designed to promote an image of liberalization that reinforces international legitimacy.

\section{The Arab Uprisings}

The question of why Algeria did not participate in the Arab Uprisings is a multifaceted one. Many political, social, and economic experts have explored the question of why Algeria did not participate in the Arab Uprisings in the same manner as Tunisia, Egypt and Libya. For instance, Algeria and Tunisia have similar histories of secular authoritarian regimes though Algeria is more conservative than Tunisia. Tunisia's history as an independent state has been more open to modernist approaches to policies and infrastructure, likely because colonial Tunisia did not experience the same level of devastation that colonial Algeria did. While both states have secular histories, the FLN regime of Algeria has promoted an Islamic state identity. This identity, while not directly incorporated into each and every institution of the state, has still integrally affected the approach of governance. So, while drawing connections between states that participated in the uprisings and states that did not can be useful, internal considerations have struck me as the most compelling explanations. Algeria's entrenchedness in the oil industry and the economic implications of such an economy has been another common area of focus explored by researchers considering why Algeria did not see the same participation in the regional uprisings. 
Algeria's economy is so significantly bolstered by the oil rents accrued by the oil production within the large geographic territory that the centralized government of the state is afforded the privilege of ultimate authority. Rentier states have the power to keep the status quo. One of the consequences of living, as a civilian, in an oil rentier state is that, on some level, individuals are sacrificing their right to representation by virtue of the low taxes imposed on them. Algeria is the only North African state to rely so heavily on oil income and industry (Lust, 2014). This oil factor links Algeria to the Gulf in a way that the rest of the North African states are not, perhaps lending a regional legitimacy by linking the FLN regime to the regimes of the Gulf.

A significant catalyst of the 2011 protests across Tunisia, Libya, and Egypt was a pattern of economic disenfranchisement, especially within the younger demographics of the states. The call for democracy was intertwined with a hope that democratic process would shift the balance of the economy as well as enforce more equitable distribution of state wealth. Algeria, for the last several years, has faced a similar situation. According to World Bank reports (2015), Algeria's unemployment rate has been resting around $10 \%$ since 2010 , while the unemployment rate of women is at $16.3 \%$ and the rate for young Algerians has rested at $24.8 \%$. All the same, as political turmoil erupted in the neighboring countries, the ripple effect into Algeria was minor. In the aftermath, several researchers have explored the whys and why-nots of Algeria's lack of significant participation in the Arab Spring.

Another primary reason that has been cited is the country's intense and violent colonial history and the resulting independence struggle, which was similarly devastating. This collective memory can likely account for the reticence of older generations to push for reform. Similarly, there is collective memory of the equally brutal civil war of the early 1990 s into 2002 , which is still fresh enough to be more relevant in the minds of younger demographics. This, more so than 
a memory of the independence struggle, could explain the lack of a youth driven revolution such as occurred in Egypt, Libya, and Tunisia. Compounded with other factors, such as the unique stability oil lends to the regime, these arguments about Algeria's participation in the uprisings are certainly compelling.

From my research, I have selected an additional argument that suggests that the influence of Algeria's multicultural society, while it is vibrant enough to sustain the string of protests and internal uprisings, is not yet strong enough to make a tangible push for democracy (Iratni, 2014).

The historical DNA of Algeria has designed the political structure that exists in Algeria today. Alongside this storyline, there is a highly integrated approach to language that the colonial and independent Algerian states have each taken that lead to an understanding of the modern day implications of language choice, Algerian identity, and the future of the Algerian regime. Down the line, could changes to these internal considerations about the economy, employment and wealth distribution, identity questions, and multicultural policies precede a shift into democratization?

\section{Algeria's Politico-linguistic Context}

Language is a fundamental facet of daily life and it has provided a foundation for a long history of studies in a variety of disciplines: sociolinguistics, anthropology, political science, sociology, and even more fields. Moreover, language trends can be understood alongside many of the grounding principles of these areas of study. For instance, the term language rationalization harkens to Max Weber, a $19^{\text {th }}$ century sociologist, whose definition of rationalization refers to the "process by which a state establishes efficient and orderly rule." 
Language rationalization, by that account, reflects how a state uses language and language policies to support and reinforce an efficient, orderly infrastructure. (Laitin, 1992, p.10) The Arabization policies of Algeria (and those of neighboring states) are clear cases of language rationalization. In the case of this discourse, language rationalization can be understood as a hegemonic tool used by colonial powers and domestic powers alike within the region of North Africa.

As demonstrated in the previous historical account, Algeria's history includes a strong through line of language hegemony, which is noted as an often-overlooked factor in the political, economic, and social infrastructures of the state (Benrabah, 2014). The current and historical demographics of the state reflect the implications that come with such language power structures. As Laitin's assessment reminds us: “...language policies that recognize all groups put heavy constraints on a young state, making more difficult the development of educational materials..."(p.63) and other necessary institutional components of state building. Essentially, while it is more culturally sensitive to promote a linguistically diverse country, from a state perspective, multilingualism does make the system more complex. Checks and balances between how a state like Algeria stabilizes itself in the wake of significant change, (i.e. a war for independence) and how that state might recognize the multiplicity of its citizenship make for a highly complex and challenging linguistic story.

\section{Algeria's Modern Context}

Today's Algeria is an example of a multilingual state, despite the state sponsored idea of monolingualism entrenched in their Algerian identity stake. Within the language dynamics, there is an enmeshed series of alignments between the social ideologies often represented by each 
language. For instance, Kabyle speakers often elect to speak French to make explicit statements and delineations about their identity. Conversely, within the formal sphere (i.e. on an institutional level) there is a dichotomous relationship between French and Arabic, both of which exist in highly standardized forms and are both utilized in the formal sphere (Dourari, 2014). This is contrasted against the collection of Berber languages, which do not have standardized forms or are only beginning to undergo that sort of deliberate language structuring.

Though Algeria's Arabization policies have rationalized Arabic in many spheres, it remains true that French is still a dominant feature of the Algerian economy. Both private and public sector jobs call for French language competency (Benstead \& Reif, 2013). So, in realistic terms, Algeria has never successfully undergone a "total Arabization" since many of the economic, judicial, and higher academic institutions still function in the French language.

The official language of modern Algeria is Arabic (CIA, 2013), with Classical Arabic touted as the language behind the state's prescription of national identity. Even three decades past independence and in the heat of the Arabization policies, French remained a lingua franca. Academically, institutionally, and in the media, French was still prominent in the daily lives of Algerians (Morsly, 1984). To many Algerians, the French language represented the cooption of Arab identity, a secular oppression, a constraining of authentic identity. "[T]he refusal to recognize French language and culture is seen as a way of disposing of the influences left by the 'infidels"' (Benrabah, 2010, p.64).

This rich history of language interaction exists in multiple spheres. Certain environments calls for certain languages, or certain variations of those languages. Some are used in social spheres, others are produced in formal spheres. As in many multilingual environments, 
codeswitching ${ }^{11}$ in Algeria is a daily reality. According to Laitin (1992), the upper class of Algeria is "typically triglossic, in [Standard Arabic], French, and a mother tongue." In Algeria, if individuals cannot speak French with a high level of competence (and many can't because it's typically taught in higher and private education), they will not have access to higher paid jobs. Benstead and Reif's 2012 survey on a university campus in Algiers showed that there is statistically significant support for language and socioeconomic stratification alignment. Survey data indicate that language serves as a piece of "symbolic capital" and supports the prediction that survey respondents with a higher income are more likely on a statistically significant level to respond in French, given a choice between French and standard Arabic (Benstead \& Reif, 2013). Benstead and Reif use this data to support Bourdieu's contention that income and economic factors are valid indicators of language preference. This link between language and economic stratifications has already been made in these studies but I suggest that they should be expanded to consider how language attitudes and cultural delineations might have bolstered the protests that were connected to economic disenfranchisement and lack of employment opportunities.

In any type of language environment, people develop both overt and covert attitudes about language. Moreover, what people say they believe about a language or they way they use it might not reflect how they use it in actuality. This is not, typically, due to any conscious dishonesty; rather, people are largely fundamentally unaware of how they actually use language. The behavior of using French, using Arabic, or using one of the Berber languages might serve to tell researchers about an individual's covert attitudes about language or religion or politics of which she might be in fact be unaware (Walters). In turn, these assessments of how language

\footnotetext{
${ }^{11}$ Codeswitching is a common tactic in multilingual environments where speakers alternate (codeswitch) between their languages, selecting the most appropriate variation for the circumstances.
} 
aligns with certain sets of beliefs or behaviors could help to illuminate voting patterns within certain demographics.

\section{Linguistic Theory}

Though there are several interdisciplinary focuses that consider linguistic and political environments, in general, I contend that many political science studies have overlooked the helpfulness of language studies to explore their area of interest. Language studies can be undertaken from a direct or indirect angle, making them versatile. A researcher can either ask directly about a respondent's response to a particular language or can indirectly explore how their behaviors and beliefs are subtly directed by their covert attitudes about and toward languages. For the purpose of this thesis, I want to suggest that political science would do well to incorporate indirect language attitude study methodologies into political studies.

Indirect language attitude studies like the Matched Guise technique could potentially account for the gray areas in the "language issue" of political science. Certainly language is not the sole explanation for complex systems but it can help to explain patterns. I contend that it has been underutilized as a tool to explore those patterns. Despite language being omnipresent, it remains that it is often overlooked. It can help to get into a closed society's attitudes. It can deal with both social domain and formal domain languages. Though Dourari brushed French off as only in the formal domain, he is illustrating what is at stake in "the language issue" because despite being distinct domains, the formal and informal are inextricably linked on macro and micro levels. In Algeria, it's important that researchers utilize language studies because Algeria's people are aware of how language is used as a tool of the state. Especially because of the political censors in 
place in Algeria, using language attitudes as a way to gage political behavior might help to circumnavigate those censors while still being sensitive to them.

The Matched Guise technique (Lambert et al., 1965) developed during the 1950s in Montreal by Lambert and his colleagues (Garrett, 2010) has been used successfully in many explorations of mono-, bi-, and multi-lingual language environments to solicit information about subconscious language attitudes that might impact the behavior and beliefs of individuals in these multi-lingual environments. This methodology has been employed in the postcolonial and post-national environment of Taiwan to explore the implication of the politicization of languages by China's colonial presence and the treatment of indigenous Taiwanese (Chang \& Lu, 2014). It has also been utilized by Chakrani (2011) in a sociolinguistic study of Morocco. These two studies have particular relevance to my argument and are relatable to the context of Algeria due to parallels in language policy and cultural context. I propose using this technique as a methodological approach to explore how language attitudes in Algeria might affect political behavior or have implications for assessing the future of a complex political arena such as Algeria.

This technique has been successfully used to assess whether certain traits are associated with certain languages or language variations (Drager, 2014), which makes it an appropriate selection for addressing the topic in question: whether there are certain political beliefs are regularly associated with speakers of certain languages or language variations in Algeria. Especially at a time when the FLN regime will soon see a change in leadership, these studies might help explore how language trends could predict the viability of future leaders or the influence of liberalizing language policies introduced by the regime. 
The matched guise technique is useful because you can expand it to include many languages. It's a flexible tool and the more languages that are included, the more complex the technique gets. The methodology does require being able to find someone who can produce all of the variations; however, this is what establishes control and provides a reliable set of survey materials. Ideally, it will be one (or possibly two people) who can authentically produce all of those variations.

\title{
Discussion
}

\author{
My only ambition is to invite the reader to look in a new way at a situation, \\ whose description and assessment are in great part dominated by emotional \\ reactions, ethnic and linguistic identities, ideological and political biases, and \\ reductive misrepresentations. (Gafaïti, 2002) ${ }^{12}$ (p. 20)
}

Gaps in the previous research and the construction of a largely dichotomous, rivalry-focused political scene make a compelling argument that the incorporation of a more comprehensive, inclusive set of language studies could shed light on the complex situation of Algerian society, identity, and political future. Especially in light of a variety of shifts occurring in Algeria and the surrounding region, I propose that this is the time to be honing in more directly on the Algerian context. Past language studies have been limited by censorship and restrictions and there isn't a profound existing set of sociolinguistic studies directly in relationship to the state's political patterns. Having a history of an almost-democratization, Algeria shows a recent series of changes could indicate a change in the regime. While the rest of the region saw dramatic and

\footnotetext{
${ }^{12}$ Italics added by author for emphasis.
} 
violent political demonstrations and, in the case of Tunisia, a fairly rapid democratic transition, these subtle changes in Algeria could signal a similar but slower shift into democratic reform. Will the changes relating to leadership, freedom of the press, and more inclusive cultural and linguistic policies have an impact or will they simply function as appeasements?

Now is the time to begin establishing more in-depth interdisciplinary studies in order to lay a framework to which future studies can be compared. These studies could also be adjusted and run in the neighboring countries so as to foster a regionally comprehensive and comparative foundation for politico-linguistic research in North Africa.

Firstly, there is the question of leadership. President Bouteflika will no longer be a viable leader in the coming years, despite his electoral win in 2014. The case of Algeria is also unique in the Maghreb due to the strength maintained by the FLN, the political party of the current president, Bouteflika. In a series of articles in Aljazeera in the lead up to the April 2014 elections, his leadership skills were called into question due to his ailing health and inability to participate. He refrained from giving any public speeches prior to the elections and only announced his candidacy two months prior to the elections. Despite this, and reinforcing the polity's categorization as a single party dominant state, Bouteflika won the election for his fourth term in office.

This inevitable shift in leadership could prompt more societal pushes for democracy or it is possible that his replacement will be from within the FLN. In this case, it could simply be a continuation of the same regime.

Secondly, censorship and press restrictions are shifting. Though Algeria's constitution allows freedom of the press, the reality since the Civil War has been that press has been state run and 
highly censored. For years, Freedom House has identified Algeria as "Not Free" in their assessment of civil liberties. Only recently has press autonomy begun to change and the Freedom House ranking has shifted from "not free" to "partially free." Even so, there still remain specific topics that see censorship by the regime, such as reflections on the current leadership, terrorist activities, and anything that could be conceived as pro-Islamist.

State agencies regularly engage in both direct and indirect censorship. In January, a media blackout was imposed on coverage of the terrorist attack at the British Petroleum-operated gas plant in In Amenas. The Ministry of Communications blocked publication of two newspapers on May 19 when they attempted to print articles stating that Bouteflika's health had deteriorated, despite official reports to the contrary. Self-censorship also remains widespread, motivated largely by a fear of defamation charges or other forms of government retaliation. (Freedom House, 2014)

In a state where social distrust is tangible and censorship is the status quo, citizens are afraid of talking honestly and self-censorship, even by publications that are privately run, is common. Environments such as this stifle the ability to gather authentic and comprehensive survey responses. With this in mind, if the censorship restrictions continue to loosen and make way for more diverse reporting that sees less self-censorship, I contend that a similar openness toward further liberalizing policies (that could precede democratization) might be on the horizon.

Thirdly, there has been a recent shift in the ever-present language policies of Algeria. Despite years as a banned language under the FLN regime, in the wake of the Black Spring, Tamazight was labeled a national language (Raymond \& Ali, 2014) and the state is allowing it to be taught in certain schools. Bilingual education could indicate a shift towards more pluralistic, inclusive 
educational policies that could pave the way for a multicultural, possibly even multinational state. Citing the High Commission for Berber Affairs (HCA) statistics (2012), Benrabah (2014) demonstrates the initial increase of Tamazight students from 1995 to 2012, though increasingly the state has under supported those efforts to foster Tamazight-inclusive education. This drop in enrollment and support for the programs seems to suggest that this instance of the state's liberalized language policies — a nod to multiculturalism — could be an appeasement rather than a real precursor to lasting change. Wei (2008), considering the case of Taiwan under the colonial rule of China, makes the salient point that the "post-nationalistic" context of Taiwan is multicultural, having moved forward from the monolingual national vision of a China-dominated Taiwan. Her study lends support to my contention that with multiculturalist tides, comes a complimentary tide of democratization.

Are these changes simply appeasements or are they signs of possible democratization at a slower place? At this juncture, I would not go so far as to call them predictive of the political condition of future Algeria. However, I would caution against writing them off altogether. These shifts are signals that I believe are significant enough to warrant the implementation of more in depth, interdisciplinary studies that utilize language and cultural signals to track political patterns.

\section{Proposed Methodology}

I propose using the Matched Guise technique as the foundation for a possible survey. In the case of Algeria, it would be appropriate to design a set of multi-lingual vignettes, which are matched in content and vary in language. Respondents would be exposed to these vignettes that feature standard varieties of French and Modern Standard Arabic (MSA), the commonly spoken 
Algerian variation of colloquial Arabic Darija, and a variety of the Berber languages, certainly Kabyle. To control for ideological influence, these samples would ideally be neutral or matched in their content and therefore, it would follow that any answers to questions asked after exposure to the sample would be based on the individual's reactions, conscious or subconscious, to the language the clip was presented in. The better the samples match in terms of content, the less likely it will be for respondents to be taking cues from the content of the sample as the basis for their opinions about leadership qualifications.

It would also be important to expose respondents to each sample/language and account for gender distinctions. Without controlling for gender, there might be a spurious relationship between language variations, the language attitudes associated with them, and the assessment of political leadership skills. It might also be appropriate to explore whether gender has a significant influence over differing language attitudes. A study in Tunisia has shown that women are more likely to have fewer negative associations with the French language, while men are more likely to have negative associations left over from decades of French colonialism and language oppression (Walters, 2011).

Garrett's (2010) text outlines a variety of pros and cons of using the Matched Guise technique as a reliable methodology for exploring language attitudes in multilingual and multiethnic environments. He discusses the question of authenticity of accent as a common issue, relating to whether the accent is authentic or mimicked as well as the community that the accent variation might stem from. Garrett also highlights the issue of the "neutrality" of the content respondents are exposed to and whether the content could influence the reactions of the respondent. Despite the Matched Guise Technique's usefulness and many successful studies, due 
to its strong history of use, there is certainly a long list of points of controversy. I would like to echo these concerns and add an additional caution to the list:

In the theoretical foundation of sociolinguists, it is argued that it is the "quotidian, mundane communication" that influences an individual's identity, rather than their identity dictating their behavior and beliefs (Benstead \& Reif, 2013). This supports my contention that there is potential for language studies such as the Matched Guise Technique to reinforce negative structures of language hegemony. By asking respondents to reproduce their language attitudes (even and perhaps especially without their knowing the significance of their responses), the survey could be entrenching those attitudes that might be problematic.

Chakrani (2011) reminds us that covert language attitudes (beliefs that people have that drive the way they behave and think about things) aren't necessarily going to be articulated. For example, if asked to answer the specific question: "What do you think about Berber languages or French?" how people answer this question likely will not reflect what they really think or how they really behave. These are unconscious attitudes. MG techniques are useful in exposing covert attitudes. But, by asking these (MG) questions, researchers might be cementing attitudes that are harmful. Even if the respondent may not pick up on what you're rooting around for, they still might solidify these behaviors further. Chakrani's article challenges the existing literature on the "trichotomous" language system of Morocco, which parallels Algeria's. He insists that as studies reinforce the attitudinal conflict between SA, MA \& French, there is potential to only further promote the hegemonic language interaction. Though unique in its own ways, Algeria's infrastructure and linguistic make up mimic Morocco's in enough ways to suggest that a similar conclusion can be drawn confidently. 
The Berber Spring and the Berber Cultural Movement that developed from the pluralistic, cultural movements calling for a more tolerant language environment couched in a democratic regime, perhaps, make a subconsciously similar argument. Citizens of multilingual communities would certainly be aware of the reality of codeswitching and de-emphasizing the formal language stratifications would, over time, soften the attitudes that contribute to language hegemony. For instance, those attitudes about French specifically viewed as "modern" or colloquial Arabics as unable to "tackle formal topics and discussions of a technical nature" as is believed in Morocco. (Chakrani, 2011, p. 168-9)

\section{Conclusion}

While language attitude studies are certainly valuable to exploring how complex linguistic structures affect state infrastructure and promote or challenge the advancement of society, it would be pertinent to be sensitive to how relying on these studies might only cement further the hegemony that disadvantages the greater demographic. Chakrani argues that reinforcing the language attitudes that "polarize" the languages in question, even unintentionally, by means of a sociolinguistic study, might only further entrench the language attitudes. As such, any efforts to implement these types of language studies should be done with attention to the design of the survey so as to avoid reinforcing the negative language power structures.

To round off this exploration of Algeria's history and the history of literature that has been developed on the region, I return to Iratni's (2014) assessment of Algeria's participation in the uprisings of 2011. His research highlighted the continuous presence of multilingual and multicultural factors on the ground in Algeria that, due to state identity and the stability of the oil economy, do not play a dynamic role in the governance of the state. Iratni concludes that that 
continued power of the regime comes down to the question of oil revenues and wealth distribution. Despite the omnipresence of multiculturalism that is a core characteristic of the state, if the economic infrastructure continues to make minor concessions to support the population, the multicultural reforms being called for will not have the strength to prompt a significant shift in the regime. Though in general I can support his argument, I also believe that his assessment might contribute to the literature that Gafaiti (2002) refers to as "reductive misrepresentations." Language attitude studies have the potential to deliver a more in-depth evaluation of these political assessments. Though many researchers, and many of the sources I have pulled from, do rely on multidimensional assessments of Algeria and its future, my argument demonstrates the need for a much more comprehensive interdisciplinary approach. 


\section{References}

Addi, L. (2014). Algeria. In Ellen Lust (Ed.), The Middle East (pp. 429-447). London, UK: Sage Publictions.

Benrabah, M. (2010). Language and Politics in Algeria. Nationalism and Ethnic Politics, 10(1), 59-78. http://doi.org/10.1080/13537110490450773

Benrabah, M. (2014). Tensions between Arabophones and Berberophones in Algeria. M. Ennaji (Ed.). New York, NY: Routledge.

Benstead, L J. \& Megan Reif. (2013). Polarization or Pluralism? Language, Identity, and Attitudes towards American Culture among Algeria's Youth. Middle East Journal of Culture and Communication, 6, 75-106.

Berger, A-E.. (2002). The Impossible Wedding: Nationalism, Languages, and the Mother Tongue in Postcolonial Algeria. Anne-Emmanuelle Berger (Ed.). Ithaca, NY: Cornell University Press.

Chakrani, B. (2011). Covert Language Attitudes: A New Outlook on the Sociolinguistic Space of Morocco. Selected Proceedings of the $40^{\text {th }}$ Annual Conference on African Linguistics. Eyamba G. Bokamba et al. (Eds.), 168-177. Somerville, MA: Cascadilla Proceedings Project.

Chang, Y., \& Lu, J. (2014). Language Stereotypes in Contemporary Taiwan: Evidence from an Experimental Study. Journal of East Asian Studies, 14(2), 211-248. 
CIA World Factbook. (2013). Algeria. Retrieved from:

https://www.cia.gov/library/publications/the-worldfactbook/geos/print/country/countrypdf_ag.pdf

Dourari, A. (2014). Algeria: Cultural multiplicity and unity dialectics. M. Ennaji (Ed.). New York, NY: Routledge.

Drager, K. (2014). Experimental Methods in Sociolinguistics. In Holmes, J \& Hazen, K (Ed.), Research Methods in Sociolinguistics: A practical guide. Hoboken: Wiley.

Freedom House. (2014). Algeria. Retrieved from https://freedomhouse.org/report/freedompress/2014/algeria\#.VVaqNFVViko

Gafaïti, H. (2002). The Monotheism of the Other: Language and De/Construction of National Identity in Postcolonial Algeria. Anne-Emmanuelle Berger (Ed.). Ithaca, NY: Cornell University Press.

Garrett, P. (2010). Attitudes to Language. Cambridge, UK: Cambridge University Press.

Ibrahim, Y. (1988, October 16). The World; Algeria's Unhappy Revolutionary Example. The New York Times. Retrieved from http://www.nytimes.com/1988/10/16/weekinreview/theworld-algeria-s-unhappy-revolutionary-example.html

Iratni, B. (2014). Why no Arab Spring in Algeria?: Questioning multiculturalism and democracy experiments. M. Ennaji (Ed.). New York, NY: Routledge.

Jamal, A. (2007). Barriers to Democracy: The other side of social capital in Palestine and the Arab World. Princeton, NJ: Princeton University Press. 
Laitin, D D. (1992). Language repertoires and state construction in Africa. New York: Cambridge University Press.

Lambert, W. et al. (1965). Evaluational Reactions of Jewish and Arab Adolescents to Dialect and Language Variations. Journal of Personality and Social Psychology, 2(1) 84-90.

Liverani, A. (2008). Civil Society in Algeria: The political functions of associational life. New York, NY: Routledge.

Micaud, C. A. (1974). Bilingualism in North Africa: Cultural and Sociopolitical Implications. The Western Political Quarterly, 27(1), 92-103. http://doi.org/10.2307/446397

Morsly, D. (1984). La Langue Étrangère: Reflexion sur le statut de la langue française en Algérie. Le Français dans le Monde (189) 22-26.

Nield, R. (2014, March 2). Algeria: A fourth term for Bouteflika? Aljazeera. Retrieved from http://www.aljazeera.com/indepth/features/2014/03/algeria-fourth-term-bouteflika2014329222653935.html

Oxford English Dictionary. (n.d.). Barbary. Retrieved from http://www.oed.com.proxy.lib.pdx.edu/view/Entry/15400\#eid27751124

Raymond, P. A. \& Ali, M. (2014, July 6). Infographic: The Berber struggle. Aljazeera. Retrieved from http://www.aljazeera.com/indepth/interactive/2014/06/infographicberber-struggle-20146109379433180.html

Said, E. (1977). Orientalism. New York, NY: Random House.

Stone, M. (1997). The Agony of Algeria. New York, NY: Columbia University Press. 
Taleb Ibrahimi, K. (1997). Les Algeriens et Leur(s) Langue(s): Elements pour une approche sociolinguistique de la société algérienne. Alger: Les Editions El Hikma.

Walters, K. (2011). Gendering French in Tunisia: language ideologies and nationalism. International Journal of the Sociology of Language, 2011 (211) 83-111.

Walters, K. (n.d.) Language Attitudes. In BrillOnline Encyclopedia of Arabic Language and Linguistics. Retrieved from http://referenceworks.brillonline.com/entries/encyclopediaof-arabic-language-and-linguistics/language-attitudes-EALL_COM_vol2_0084

Wei, J. M. (2008). Language choice and identity politics in Taiwan. Lanham, MD: Lexington Books.

World Bank. (2015). Algeria. Retrieved from http://www.worldbank.org/en/country/algeria/overview 